(O2020. Sudiarmanto dan Sumarmi. Published by Universitas Airlangga.

This is an open access article under CC-BY-SA license

Received: 02-01-2020, Revised: 25-01-2020, Accepted:15-02-2020, Published: 30-06-2020

RESEARCH STUDY

Open Access

\title{
Hubungan Asupan Kalsium dan Zink dengan Kejadian Stunting pada Siswi SMP Unggulan Bina Insani Surabaya
}

\section{The Correlation between Calcium Intake, Zinc Intake and StuntingPrevalence on SMP Unggulan Bina Insani Surabaya Students}

\author{
Andri Rahmad Sudiarmanto* ${ }^{1}$, Sri Sumarmi ${ }^{2}$
}

\begin{abstract}
ABSTRAK
Latar Belakang: Remaja merupakan salah satu kelompok rawan terhadap stunting karena remaja beresiko mengalami defisiensi asupan makanan baik makronutrien maupun mikronutrien. Defisiensi asupan kalsium dan zink yang merupakan mikronutrien penting bagi pertumbuhan adalah faktor resiko stunting. Stunting pada masa remaja ini akan menurunkan kapasitas dan produktivitas kerja serta dapat meningkatkan resiko kematian ibu pada saat melahirkan.

Tujuan: Tujuan penelitian ini adalah menganalisis hubungan asupan kalsium dan asupan zink dengan kejadian stunting pada siswi SMP Unggulan Bina Insani Surabaya.

Metode: Penelitian ini merupakan penelitian cross sectional dengan pendekatan kuantitatif. Dengan besar sampel 68 orang yang diambil secara acak sederhana. Pengumpulan data menggunakan pengukuran tinggi badan, food recall $2 \times 24$ jam. Data dianalisis menggunakanare teknik analisis deskriptif dan uji korelasi Kendall's-Tau serta uji ANCOVA.

Hasil: Hasil penelitian menunjukkan responden yang mengalami stunting sebesar 22,1\% dan 77,9\% normal, rata-rata nilai Z-score $1,13 \pm 0,94$. Tingkat konsumsi asupan kalsium cukup sebesar 7,4\% dan 92,6\% asupannya kurang, dengan rata-rata asupan sebesar 336,7 $\pm 326,2 \mathrm{mg}$ /hari. Tingkat konsumsi asupan zink cukup sebesar $5.9 \%$ dan 94.1\% asupannya kurang, dengan rata-rata asupan sebesar 5,7 $\pm 3,0 \mathrm{mg} /$ hari. Tidak ada hubungan antara asupan kalsium ( $\mathrm{r}=0,072 ; \mathrm{p}=0,385)$, asupan zink $(\mathrm{r}=0,124 ; \mathrm{p}=0,138)$, asupan kalsium dan zink $(\mathrm{p}=0,478)$ dengan kejadian stunting.

Kesimpulan: Asupan kalsium dan zink tidak berhubungan dengan kejadian stunting pada siswi SMP Unggulan Bina Insani Surabaya. Agar dapat mencapai pertumbuhan dan perkembangan yang sesuai, siswi dapat melakukan pemantauan status gizinya secara rutin serta berperilaku hidup bersih dan sehat.
\end{abstract}

Kata kunci: remaja, stunting, asupan kalsium, asupan zink

\section{ABSTRACT}

Background: Adolescence is a vulnerable stunting group because adolescents are at risk of macronutrient or micronutrients intake deficiency. Calcium and zinc intake deficiency are vital micronutrients for the growth factor and the risk of stunting. Stunting in adolescence will reduce the work capacity and productivity and increase the risk of maternal death in childbirth.

Objectives: This study was aimed to analyze the correlation between calcium, zinc intake and stunting prevalence on SMP Unggulan Bina Insani Surabaya schoolgirls.

Methods: The research was a cross sectional study with quantitative approach. The sample size was 68 schoolgirls, were taken by simple random sampling. The data were collected by measuring height, food recall $2 \times 24$ hours. Analysis of data used in descriptive, Kendall's-Tau and ANCOVA Test.

Results: The results showed the proportion of respondents who experienced stunting $22 \%$ and normal $78 \%$, with Zscore average at $1.13 \pm 0.94$. The consumption rate of calcium intake was sufficient at $7.4 \%$ and insufficient at $92.6 \%$, with an average at $336.7 \pm 326.2 \mathrm{mg} /$ day. The consumption rate of zinc intake 
was sufficient at $5,9 \%$ and insufficient at $94,1 \%$, with an average at $5.7 \pm 3.0 \mathrm{mg} /$ day. There is no relationship between the calcium intake $(r=0.072 ; p=0.385)$, zinc intake $(r=0.124 ; p=0.138)$, calcium and zinc intake $(p=0.478)$ with the stunting prevalence.

Conclusions: The intake of calcium and zinc doesn't related to the stunting prevalence of the schoolgirls. The scoolgirls should to regularly monitor their nutritional status and behave in clean and healthy life, in order to achieve appropriate growth and development.

Keywords: adolescence, stunting, calcium intake, zinc intake

*Koresponden:

Andri Rahmad Sudiarmanto

4dhyasta@gmail.com

${ }^{1}$ Program Studi Gizi, Fakultas Kesehatan Masyarakat - Universitas Airlangga, Kampus C, Mulyorejo, 60115, Surabaya, Jawa Timur, Indonesia

${ }^{2}$ Departemen Gizi Kesehatan, Fakultas Kesehatan Masyarakat - Universitas Airlangga, Kampus C, Mulyorejo, 60115, Surabaya, Jawa Timur, Indonesia

\section{PENDAHULUAN}

Stunting yang memiliki konsekuensi penting bagi kesehatan dan pembangunan, masih menjadi ancaman global, terutama di negara berkembang. Prevalensi anak stunting di seluruh dunia pada tahun 2014 adalah 23,8\% dan di seluruh Negara berkembang sebesar 33,5\% (UNICEF, WHO and The World Bank, 2014). Prevalensi stunting remaja Indonesia tahun 2013 berdasarkan data hasil Riset Kesehatan Dasar (Riskesdas) sebesar 35,1\% (Balitbangkes Kemenkes RI, 2013), sedangkan prevalensi stunting remaja di provinsi Jawa Timur sebesar 31,1\% dengan status gizi $10,8 \%$ remaja sangat pendek dan 20,3\% remaja pendek (berdasarkan tinggi badan menurut umur) (Trihono et al., 2015).

Menurut UNICEF, WHO and The World Bank (2014), faktor utama penyebab stunting terdiri dari tiga hal yaitu tidak seimbangnya asupan makanan yang berkaitan dengan kandungan zat gizi dalam makanan (karbohidrat, protein, lemak, mineral, vitamin, dan air), kejadian berat badan lahir rendah (BBLR), dan penyakit yang diderita. Soekarti, Soetardjo dan Almatsier (2011) menyebutkan bahwa keadaan stunting merupakan akumulasi dari pertumbuhan linear yang buruk yang terjadi akibat asupan zat gizi yang kurang dalam waktu lama dan angka kesakitan akibat penyakit infeksi yang tinggi, atau kombinasi dari dua keadaan tersebut.

Stunting terjadi melalui siklus malnutrisi ibu, dimana ibu yang mengalami hambatan pertumbuhan dan kurang gizi kronis beresiko melahirkan bayi dengan berat badan lahir rendah (Sumarmi, 2016). Menurut Aguayo dan Menon (2016), stunting yang terjadi pada masa anak-anak dapat berlanjut menjadi penyebab stunting pada periode kehidupan selanjutnya dan pada masa remaja hal ini menjadi hal yang merugikan karena dapat menyebabkan terjadinya gangguan pada perkembangan reproduksi atau masa pubertasnya sehingga dapat mengakibatkan kehamilan beresiko stunting (Victora et al., 2008).

Remaja (adolescents) adalah penduduk yang berusia 10-19 tahun. Pada masa remaja ini, terjadi lonjakan pertumbuhan (growth spourts) yang ditandai dengan kenaikan berat badan atau tinggi badan (Susetyowati, 2016)(Susetyowati, 2016). Adriani dan Wirjatmadi (2012) menyatakan bahwa remaja memiliki kebutuhan asupan zat gizi yang unik jika ditinjau dari sudut pandang biologis, psikologis dan sosial. Peningkatan pertumbuhan fisik dan perkembangan pada remaja serta perubahan gaya hidup dan kebiasaan makan, menjadikan kebutuhan gizi pada masa remaja perlu mendapat perhatian khusus. Penelitian

Christiany, Hakimi dan Sudargo pada tahun (2009) menyebutkan bahwa dibutuhkan energi dan zat gizi lain dalam jumlah yang lebih banyak dalam percepatan pertumbuhan dan perkembangan remaja Berkaitan dengan asupan makanan, makronutrien dan mikronutrien merupakan kelompok utama nutrisi (zat gizi) dalam makanan. Makronutrien merupakan zat gizi utama yang diperlukan dalam pertumbuhan, berfungsi menyediakan energi bagi tubuh terdiri dari karbohidrat, protein, dan lemak,. Sedangkan mikronutrien merupakan zat gizi yang dibutuhkan untuk menjalanjkan fungsi tubuh, termasuk di dalamnya adalah vitamin dan mineral.(Soekarti, Soetardjo and Almatsier, 2011). Menurut Jumirah, Lubis dan Aritonang (2006) status asupan makronutrien dan mikronutrien terutama energi didapatkan melalui konsumsi karbohidrat, protein dan lemak berkaitan dengan stunting. Penelitian

Chastity pada tahun 2017 menyebutkan bahwa faktor resiko terjadinya stunting pada remaja adalah asupan protein, dengan OR sebesar 6,984, yang berarti bahwa resiko terjadinya stunting pada remaja dengan asupan protein kurang 6,984 kali lebih besar dibandingkan pada remaja dengan asupan protein yang cukup. Sundari dalam penelitiannya pada tahun 2016 menyebutkan bahwa asupan protein memiliki hubungan yang bermakna dengan zscore TB/U pada balita. Penelitian ini juga menyebutkan bahwa kekurangan asupan protein yang berlangsung lama dapat menyebabkan terhambatnya pertumbuhan tinggi badan, meskipun asupan energi tercukupi. 
Mikronutrien yang berkaitan dengan stunting antara lain yaitu zink, kalsium, vitamin D, Fe, dan lain-lain (Jumirah, Lubis and Aritonang, 2006). Hasil penelitian Amelia, Syam dan Fatimah pada tahun 2013 menyebutkan bahwa antara asupan energi, protein dan zink berhubungan dengan status gizi santri. Penelitian Armelia pada tahun 2014 menyebutkan bahwa tingkat kecukupan energi, kalsium tinggi badan ayah, tinggi badan ibu, pendidikan ayah, pendidikan ibu serta pendapatan keluarga dan zink berhubungan secara signifikan dengan pertumbuhan linier anak.

Kalsium adalah mineral yang berperanan sangat penting bagi metabolisme tubuh, sebagai penghubung antar syaraf, dalam kerja jantung dan pergerakan otot. Massa tulang optimal terjadi selama masa remaja yaitu antara usia 11-14 tahun pada anak perempuan dan antara usia 14-16 tahun anak laki-laki, dimana sebanyak 51\% dari massa tulang puncak terakumulasi selama pertumbuhan pubertas dan mencapai $37 \%$ dari kepadatan mineral tulang dari orang dewasa (Gracia-Marco et al., 2010). Angka Kecukupan Gizi Yang Dianjurkan remaja (10 - 18 tahun) di Indonesia yaitu sebesar $1.200 \mathrm{mg}$ per hari (Kemenkes RI, 2013b). De Assumpcão et al. (2016) dalam penelitiannya di Sao Paulo Brazil menyebutkan bahwa prevalensi asupan kalsium yang tidak memadai sebesar $88,6 \%$ dari total populasi, yaitu sebesar $85,1 \%$ pada remaja laki-laki dan $92,2 \%$ pada remaja perempuan. Penelitian lain yang dilakukan Fikawati, Syafiq and Puspasari (2005) pada murid SMU di Bogor menyebutkan jika asupan kalsium yang berasal dari susu dan hasil olahannya ditambah suplemen kalsium pada remaja hanya sebesar $526,9 \mathrm{mg} / \mathrm{hari}$, yang berarti kurang dari anjuran sebesar $1.200 \mathrm{mg} /$ hari.

Mikronutrien lain yang juga berperanan penting dalam pertumbuhan adalah zink. Kekurangan zink akan berpengaruh terhadap jaringan tubuh (Almatsier, 2001). Kekurangan zink pada usia sekolah akan mengakibatkan gangguan pertumbuhan fisik (stunting) dan gangguan perkembangan sel otak (Rosrnalina and Ernawati, 2010). Berdasarkan Peraturan Menteri Kesehatan Republik Indonesia Nomor 75 Tahun 2013 tentang Angka Kecukupan Gizi Yang Dianjurkan Bagi Bangsa Indonesia yaitu antara 13-16 mg per hari pada remaja putri, sedangkan pada remaja putra 14-18 mg per hari. Penelitian yang dilakukan oleh Trisnawati (2014) menunjukkan bahwa di Jawa Tengah terdapat 94,2\% subjek penelitian memiliki asupan zink kurang dari $70 \%$ AKG. Pada penelitian lain yang dilakukan oleh Sulistianingtias Laila (2017) didapatkan hasil bahwa 39,4\% subjek penelitian memiliki asupan zink kurang.

Penelitian Rahmawati dkk. (2017) menyebutkan bahwa terdapat perbedaan tingkat kecukupan protein $(\mathrm{p}=0,007)$, zink $(\mathrm{p}=0,005)$, kalsium $(\mathrm{p}=0,025)$, dan $\mathrm{Fe}(\mathrm{p}=0,034)$ pada remaja putri stunting dan non stunting. Sulistianingtias Laila E. pada penelitiannya tahun 2017 menyebutkan bahwa kejadian stunting pada remaja di Sukoharjo Jawa Tengah berhubungan dengan asupan zink sesuai hasil uji statistik chi square yang dilakukan antara asupan zink dengan kejadian stunting $(\mathrm{p}=0,001)$.

Stunting yang terjadi pada masa remaja dapat mempengaruhi perkembangan reproduksi atau masa pubertas dan merupakan konsekuensi yang merugikan bagi siklus kehidupan berikutnya, terutama pada perempuan karena pada masa kehamilan beresiko menghasilkan keturunan stunting (Aguayo dan Menon, 2016). Penelitian Sumarmi (2016) juga menyebutkan bahwa ibu dengan perawakan pendek beresiko melahirkan bayi stunting, yang mencerminkan keadaan malnutrisi antar generasi. Penelitian ini bertujuan untuk menganalisis hubungan asupan kalsium dan zink dengan kejadian stunting pada siswi SMP Unggulan Bina Insani Surabaya.

\section{METODE}

Penelitian ini merupakan penelitian payung menggunakan rancangan cross sectional yang dilakukan oleh Sumarmi dkk. (2017) melalui persetujuan dari komisi etik dari Fakultas Kesehatan Masyarakat Universitas Airlangga dengan nomor 546-KEPK. Variabel yang digunakan yaitu variabel independen (data asupan kalsium dan zink), variabel dependen (data kejadian stunting) dan variabel perancu (data asupan protein), bersifat observasional analitik karena tidak memberikan intervensi atau perlakuan terhadap sampel penelitian.

Lokasi penelitian di SMP Unggulan Bina Insani Surabaya. Populasi dalam penelitian adalah seluruh siswi kelas VII, VIII dan IX pada SMP Bina Insani Surabaya berusia 13 - 15 tahun sebanyak 81 orang. Besar sampel dalam penelitian ini sebesar 68 orang, dihitung menggunakan rumus Slovin, diambil menggunakan teknik pengambilan sampel acak sederhana (simple random sampling). Pengumpulan data asupan kalsium, zink dan protein diperoleh melalui tingkat konsumsi berdasarkan hasil food recall 24 jam responden sebanyak 2 kali dengan hari yang tidak berurutan. Hasil yang didapatkan kemudian dianalisis menggunakan system software Nutrisurvey. Hasil analisis asupan kalsium dan zink kemudian menurut R. Gibson (2005) dapat dikategorikan menjadi 2 kategori, yaitu cukup (jika tingkat konsumsi $\geq 77 \%$ AKG) dan kurang (tingkat konsumsi $<77 \%$ AKG). Status stunting diperoleh dari pengukuran antropometri tinggi badan. Hasil pengukuran tersebut kemudian dianalisi menggunakan system software WHO Anthro Plus yang menghasilkan nilai Z-Score TB/U. Nilai tersebut dibandingkan dengan kategori status gizi remaja menurut Kemenkes RI tahun 2011 berdasarkan Tinggi Badan menurut Umur (TB/U), dikatakan stunting jika Z-Score TB/U berada dibawah -2 SD. Selanjutnya nilai tinggi badan dan nilai Z-score TB/U dikategorikan dalam status gizi berdasarkan tinggi badan menurut umur (sangat pendek, pendek, normal, tinggi) dan status stunting (stunting, normal). 
Analisis data dilakukan dalam pengolahan data hasil penelitian menggunakan teknik analisis deskriptif yang dilakukan dengan menyajikan nilai rata-rata, maksimum, minimum dan standar deviasi dari variabel status stunting, tingkat asupan kalsium, dan tingkat asupan zink. Selain itu disajikan dengan menggunakan tabel distribusi frekuensi untuk melihat proporsi dari masing-masing kategori. Selanjutnya dilakukan analisis inferensial dilakukan dalam uji hubungan antara dua variabel yaitu status stunting dengan tingkat asupan kalsium, dan tingkat asupan zink menggunakan uji korelasi Kendall's-Tau dengan tingkat kepercayaan $95 \%(\alpha=0,05)$.

\section{HASIL DAN PEMBAHASAN}

Tabel 1. Distribusi Responden berdasarkan Umur pada Kelompok Status Stunting

\begin{tabular}{ccccc}
\hline \multirow{2}{*}{ Karakteristik } & \multicolumn{2}{c}{ Status Stunting } & N & Total \\
\cline { 2 - 5 } & Stunting & Normal & 7 & $\%$ \\
\hline Umur & & 6 & 43 & 10,3 \\
12 tahun & 1 & 34 & 17 & 63,2 \\
13 tahun & 9 & 13 & 1 & 25,0 \\
14 tahun & 5 & 1 & $\mathbf{6 8}$ & $\mathbf{1 0 0 , 0}$ \\
15 tahun & 0 & $\mathbf{5 3}$ &
\end{tabular}

Tabel 1 menunjukkan karakteristik responden dalam penelitian ini yang berjumlah 68 siswi, dengan rentang usia 12 - 15 tahun, dengan proporsi terbesar yaitu pada kelompok umur 13 tahun sebesar $63.2 \%$. Hal ini menunjukkan bahwa responden dalam penelitian ini termasuk dalam kategori remaja awal dimana pada masa ini merupakan masa pertumbuhan cepat (growth spourts). Pada remaja perempuan, growth spourts terjadi 12-18 bulan sebelum menarche (10-14 tahun) dan berlanjut selama 7 tahun. Selama masa ini, terjadi percepatan pertumbuhan yang meliputi $45 \%$ pertumbuhan tulang dan $15-25 \%$ pertambahan tinggi badan (World Health Organization, 2005) dengan pembentukan massa tulang sebesar 37\%. Pada remaja laki-laki terjadi pertumbuhan otot dan tulang dengan lemak tubuh normal 12\% lebih banyak. Untuk tinggi badan remaja laki-laki terjadi penambahan sebanyak $18 \mathrm{~cm}$, sedangkan remaja perempuan lebih sedikit penambahannya(Adriani and Wirjatmadi, 2013).

Hasil penelitian menunjukkan bahwa status gizi berdasarkan tinggi badan menurut umur responden penelitian ini yaitu 2 responden sangat pendek, 13 responden pendek dan 53 responden dengan status gizi normal, dengan nilai Z-score TB/U antara - 3.59 sampai 0,61 . Sebanyak 22,1\% sampel termasuk dalam kategori stunting dan 77.9\% lainnya berada pada kategori normal. Angka kejadian remaja stunting yang didapatkan dari penelitian ini lebih rendah jika dibandingan data prevalensi stunting remaja di Jawa Timur $(31,1 \%)$ dan juga lebih rendah jika dibandingkan dengan data prevalensi stunting nasional $(30,8)$ (Balitbangkes Kemenkes RI, 2018). Sesuai dengan standard WHO, angka prevalensi $\geq 20 \%$ menunjukkan bahwa kejadian stunting di SMP Bina Insani Surabaya merupakan masalah gizi yang kronis(Kemenkes RI, 2017).

Tinggi badan merupakan parameter antropometri yang menggambarkan keadaan pertumbuhan tulang dan tumbuh seiring dengan pertambahan umur. Tinggi badan menurut umur adalah ukuran dari pertumbuhan linear yang dicapai dan dapat digunakan sebagai indeks status gizi atau kesehatan masa lampau. Indeks tinggi badan menurut umur (TB/U)(Supariasa, I Dewa Nyoman., Bakri, Bachyar., Fajar, Ibnu., dan Ester, no date) merupakan indeks yang digunakan untuk mendeteksi status stunting sebagai indikator untuk mengukur status gizi individu maupun kelompok masyarakat. Stunting merupakan keadaan kekurangan nutrisi dalam masa pertumbuhan dan dapat menghambat pertumbuhan linier (Caulfield et al., 2006).

Menurut UNICEF, terdapat dua faktor penyebab yang saling mempengaruhi status gizi yaitu faktor langsung dan faktor tidak langsung. Asupan makanan dan penyakit infeksi merupakan faktor langsung yang mempengaruhi status gizi. Sedangkan faktor tidak langsungnya yaitu akses terhadap pangan, akses terhadap pelayanan kesehatan, lingkungan yang sehat, perawatan untuk anak dan wanita, serta kebijakan pemerintah (Isdijoso, 2010). Berkaitan dengan asupan makanan, status stunting yang terjadi disebabkan kurangnya asupan zat gizi makro dan mikro baik pada masa lampau maupun pada masa sekarang. Kekurangan Energi yang didapatkan terutama terjadi akibat kurangnya konsumsi makronutrien (karbohidrat, protein dan lemak) dan mikronutrien (zink, kalsium, vitamin D, Fe, dan lain-lain)(Jumirah, Lubis and Aritonang, 2006). 
Hasil analisis asupan kalsium dan zink kemudian dapat dikategorikan menjadi 2 kategori, yaitu cukup dan kurang. Distribusi responden berdasarkan tingkat asupan kalsium dan zink dapat dilihat pada tabel berikut :

Tabel 2. Distribusi Responden Berdasarkan Tingkat Asupan Kalsium dan Zink

\begin{tabular}{lcc}
\hline \multicolumn{1}{c}{ Kategori Asupan Zat Gizi } & $\mathbf{n}$ & \% \\
\hline Asupan Kalsium : & 5 & 7,4 \\
$\quad$ Cukup & 63 & 92,6 \\
$\quad$ Kurang & & 7,4 \\
Asupan Zink : & 5 & 92,6 \\
$\quad$ Cukup & 63 & $\mathbf{1 0 0 , 0}$ \\
$\quad$ Kurang & $\mathbf{6 8}$ & \\
\hline Total & & \\
\hline
\end{tabular}

Hasil penelitian menunjukkan bahwa kategori kecukupan asupan kalsium, sebagian besar termasuk kurang karena 92.6\% responden mengonsumsi kalsium sebesar <77\% AKG (kurang dari 924 mg untuk usia 10-18 tahun). Asupan kalsium yang dikonsumsi oleh 68 siswi SMP Unggulan Bina Insani Surabaya memiliki rata - rata sebesar $336,7 \mathrm{mg}$ dengan nilai minimal sebesar 25,6 mg dan nilai maksimal sebesar 1492,2 mg. Hasil penelitian ini sesuai dengan penelitian yang pernah dilakukan Fikawati, Syafiq and Puspasari (2005) yang hasilnya menyebutkan bahwa, rata- rata asupan kalsium remaja kurang dari angka kecukupan gizi (AKG) yaitu hanya 55,9\% AKG atau sebesar $559,05 \mathrm{mg} / \mathrm{hr}$, sebanyak 76,2\% remaja mengkonsumsi kalsium kurang dari 75\% AKG. Sejalan dengan penelitian yang pernah dilakukan Maspaitella dan Dieny (2012) di SMU 1 Salatiga, menyebutkan bahwa dari 74 siswi, sebanyak 69 siswi (93,2\%) memiliki asupan kalsium tergolong kurang. Alatas (2011) dalam penelitiannya di Pejaten Jakarta Selatan menyebutkan bahwa 87,67\% anak laki-laki dan perempuan yang terdaftar di Yayasan Kampung Kids memiliki asupan kalsium yang kurang, dengan rata-rata asupan kalsium harian sebesar $397 \mathrm{mg} / \mathrm{hari}$. Hasil penelitian Rahmawati dkk. (2017) menunjukkan bahwa terdapat perbedaan yang bermakna tingkat asupan kalsium pada remaja putri stunting dan non-stunting.

Kebutuhan kalsium tubuh dipengaruhi oleh ketersediaan biologis, aktivitas fisik, dan keberadaan zat gizi lain. Banyaknya konsumsi minuman ringan berkarbonat merupakan salah satu faktor menurunnya asupan kalsium, karena anak usia remaja sering meminumnya sebagai pengganti susu yang kaya akan kalsium. selain itu pada minuman ringan berkarbonat terdapat kandandungan kafein yang dapat meningkatkan pengeluaran kalsium melalui urin(Almatsier, 2010). Konsumsi zat gizi lain yang dapat menghambat absorpsi kalsium antara lain yaitu kekurangan vitamin D dalam bentuk aktif, tingginya asam oksalat dan asam fitat, konsumsi tinggi serat serta konsumsi fosfor yang lebih tinggi dari ratio optimal kalsium fosfor(Almatsier, 2009).

Jenis kelamin dan aktivitas fisik merupakan faktor lain yang dapat mempengaruhi asupan kalsium pada remaja. Remaja putri yang mengalami menstruasi sehingga harus kehilangan kalsium dalam darah, mengonsumsi kalsium dalam jumlah yang lebih sedikit dibanding remaja putra. Kekurangan kalsium juga beresiko terjadi pada mereka yang jarang melakukan aktivitas fisik (Fikawati, Syafiq and Puspasari, 2005). Selain itu, proses pengolahan makanan yang kurang baik merupakan faktor lain yang dapat mempengaruhi penyerapan kalsium dalam tubuh sebagai akibat terjadinya kerusakan akibat panas berlebih pada proses pengolahan yang berakibat menurunnya nilai gizi (Aridiyah, Rohmawati and Ririanty, 2015). Ketidakstabilan emosional seperti stress, tekanan dan kecemasan merupakan faktor lain yang dapat menghambat absorpsi kalsium (Almatsier, 2009).

Kekurangan kalsium pada masa pertumbuhan dapat menyebabkan pengurangan massa dan kekerasan tulang yang sedang dibentuk. Selain berpengaruh terhadap pertumbuhan tulang dan gigi, kekurangan kalsium juga menyebabkan sistem imunitas menurun, hambatan sistem saraf, dan gangguan daya kontraksi otot jantung(Almatsier, 2001). Asupan kalsium yang adekuat sangat penting untuk perkembangan dan pemeliharaan puncak massa tulang selama masa remaja. Massa tulang saat dewasa meningkat 40 kali dari saat baru lahir, dan antara 40\% - 60\% peningkatan massa tulang terjadi selama masa remaja(De Assumpcão et al., 2016). Kekurangan asupan kalsium pada anak-anak dan remaja akan menyebabkan gangguan pada kesehatan dan metabolisme tulang sehingga pertumbuhan dan massa tulang puncaknya akan terganggu(Bueno and Czepielewski, 2008). Armelia (2014) menyebutkan bahwa pertumbuhan linier anak memiliki hubungan yang signifikan dengan tingkat kecukupan kalsium. Penelitian Bueno and Czepielewski (2008) juga menyebutkan bahwa konsumsi makanan yang rendah kalsium, terutama pada usia pertumbuhan maka akan menyebabkan terhambat pertumbuhan di masa mendatang atau dewasa.

Angka Kecukupan Gizi Zink yang dianjurkan remaja putri (10 - 18 tahun) di Indonesia yaitu antara 13-16 mg per hari pada remaja putri (Kemenkes RI, 2013a). Hasil rata - rata konsumsi yang didapat dari recall sehari yaitu sebanyak $5.7 \mathrm{mg}$. Berdasarkan hasil tersebut dapat dilihat bahwa konsumsi zink siswi SMP Bina Insani Surabaya masih kurang dari kebutuhannya. Untuk kategori kecukupan asupan zink, sebagian besar termasuk kurang karena 94.1\% responden mengonsumsi zink sebesar <77\% AKG (kurang dari $10.01-12.32 \mathrm{mg}$ untuk remaja putri). 
Hasil penelitian ini sejalan dengan penelitian yang pernah dilakukan Trisnawati (2014) yang menyebutkan bahwa Sebagian besar (94,2\%) asupan zink subjek penelitian < 70\% dari AKG (defisit) dan sebanyak 5,8\% subjek penelitian memiliki asupan zink antara 70\%-79\% dari AKG (kurang). Penelitian lain yang pernah dilakukan Fauziah dan Irianto (2015) juga menyebutkan bahwa rata-rata asupan zink remaja di NTB dan di NTT masih kurang dari AKG yaitu berkisar antara $3.42-5.34 \mathrm{mg}$ per hari.

Dari hasil food recall, asupan zink yang rendah pada penelitian ini disebabkan karena konsumsi bahan makanan sumber zink masih kurang, dimana konsumsi bahan makanan golongan kacang-kacangan (seperti tempe, tahu, kacang panjang, buncis, dan kacang tanah) lebih dominan jika dibandingkan dengan bahan makanan tinggi kandungan zink seperti golongan daging merah, dan makanan laut. Rata - rata asupan zink yang dikonsumsi sebesar $5,7 \mathrm{mg}$ dengan nilai minimal sebesar $1,1 \mathrm{mg}$ dan nilai maksimal sebesar $18,5 \mathrm{mg}$.

Terdapat dua sumber zink yaitu sumber endogen dan sumber yang berasal dari diet dalam makanan. Sumber endogen adalah zink yang disediakan oleh pankreas dan sekresi empedu yang dilepaskan ke dalam system pencernaan. Sumber yang berasal dari diet dalam makanan diantaranya yaitu daging merah (terutama jeroan), makanan laut (terutama tiram dan moluska), daging unggas, babi, produk susu sayuran (daun dan akar) dan bijibijian(Darawati, 2016). Beberapa bahan makanan juga dapat menghambat penyerapan seng, antara lain yaitu serat dan fitat, seperti: beras, terigu, gandum, teh, kopi, kacang kedele, kacang, tumbuhan polong, bayam, dan susu(L nnerdal, 2000). Oksalat dan polifenol yang dikandung dalam beberapa makanan juga mengikat zink dan menghambat penyerapannnya(Darawati, 2016).

Penyebab umum defisiensi zink yaitu kekurangan asupan, peningkatan kebutuhan, malabsorpsi, peningkatan kehilangan zink dan gangguan pemanfaatan (Roohani et al., 2013). Zink yang diperlukan dalam berbagai faktorfaktor transkripsi dan enzim, sangat berperan dalam diferensiasi dan proliferasi sel. Kekurangan zink akan menyebabkan pertumbuhan yang terhambat, perubahan kulit, gangguan respon imun, meningkatnya kerentanan terhadap infeksi, lambatnya proses penyembuhan luka, gangguan kematangan seksual dan gangguan kesuburan(Maggini, Wenzlaff and Hornig, 2010). Kekurangan zink kronis dapat mengganggu pusat sistem saraf dan fungsi otak sehingga menyebabkan gangguan fungsi kelenjar tiroid dan laju metabolisme, gangguan nafsu makan, penurunan ketajaman indra rasa serta memperlambat penyembuhan luka(Almatsier, 2001).

Protein merupakan salah satu zat gizi makro yang penting karena fungsinya secara umum untuk pertumbuhan dan sebagai sumber energi. Semua enzim, hormon, pengangkut zat-zat gizi dan darah, matriks intraseluler dan sebagainya merupakan protein. Selain itu, asam amino yang membentuk protein bertindak sebagai prekusor sebagian besar koenzim, hormon

Hasil rata - rata konsumsi protein yang didapat dari recall sehari yaitu sebesar 46,6 gram dengan nilai minimal sebesar 8,8 gram dan nilai maksimal sebesar 125,8 gram. Tingkat asupan protein siswi di SMP Bina Insani Surabaya yaitu 57,4\% asupan protein kurang, 29,4\% cukup dan 13,2\% berlebih.

Kekurangan protein dapat menyebabkan terjadinya kurang gizi dan stunting. Rata-rata asupan protein terhadap asupan energi sehari masyarakat Indonesia sudah cukup baik, tetapi berdasarkan tingkat kecukupan protein untuk kategori kurang dan sangat kurang masih 53,4\%. Untuk kategori sangat kurang paling banyak ada pada kelompok usia 13-18 tahun sebesar 48,1\%(Damayanti, 2016). Menurut Chastity (2017), asupan protein yang rendah merupakan faktor resiko terjadinya stunting pada remaja.

Tabel 3. Hasil Analisis Hubungan Asupan Zat Gizi dengan Kejadian Stunting

\begin{tabular}{|c|c|c|c|c|}
\hline \multicolumn{2}{|c|}{ Asupan Zat Gizi } & \multicolumn{2}{|c|}{ Status Stunting } & \multirow[t]{2}{*}{ Nilai $p$} \\
\hline & & Stunting & Normal & \\
\hline \multirow[t]{2}{*}{ Kalsium: } & & $340,8 \pm 317,9$ & $335,6 \pm 331,5$ & \\
\hline & $(\min -\mathrm{maks})$ & $35,8 \pm 1087,7$ & $25,6 \pm 1492,2$ & 0,385 \\
\hline \multirow[t]{2}{*}{ Zink: } & - & $5,5 \pm 2,81,1$ & $5,8 \pm 3,1$ & \\
\hline & Maksimum & $1,1-12,7$ & $1,4-18,5$ & 0,138 \\
\hline
\end{tabular}


Hasil uji Kendall's-Tau menunjukkan bahwa tidak ada hubungan antara asupan kalsium ( $\mathrm{r}=0,072 ; \mathrm{p}=0,385)$, asupan zink $(\mathrm{r}=0,124 ; \mathrm{p}=0,138)$ dengan kejadian stunting. Untuk mengetahui hubungan asupan kalsium dan zink dengan kejadian stunting maka dilakukan analisa statistik dengan menggunakan uji statistik ANOVA, yang hasilnya ditunjukkan pada tabel berikut :

Tabel 4. Hasil Analisis Hubungan Asupan Kalsium dan Zink dengan Kejadian Stunting

\begin{tabular}{|c|c|c|c|c|}
\hline \multicolumn{2}{|c|}{ Asupan } & \multicolumn{2}{|c|}{ Status Stunting } & \multirow[t]{2}{*}{ Nilai $p$} \\
\hline & & Stunting & Normal & \\
\hline \multirow{2}{*}{ Kalsium: } & & $340,8 \pm 317,9$ & $335,6 \pm 331,5$ & \\
\hline & (min - maks) & $35,8 \pm 1087,7$ & $25,6 \pm 1492,2$ & 0,402 \\
\hline \multirow[t]{2}{*}{ Zink: } & & $5,5 \pm 2,8 \quad 1,1$ & $5,8 \pm 3,1$ & \\
\hline & Maksimum & $1,1-12,7$ & $1,4-18,5$ & \\
\hline
\end{tabular}

Hasil uji statistik menunjukkan bahwa tidak ada hubungan antara asupan kalsium dan zink dengan kejadian stunting dengan nilai- $\mathrm{p}=0,402(\mathrm{p}>0,05)$ dan nilai $\mathrm{F}$ sebesar 0,924 . Dengan menambahkan tingkat asupan protein sebagai variabel perancu, didapatkan hasil nilai $F$ sebesar 0,885 dengan nilai signifikansi 0,478 ( $>0,05)$ yang berarti bahwa secara simultan tidak ada hubungan antara asupan kalsium, asupan zink dan asupan protein dengan kejadian stunting.

Hasil penelitian ini sejalan dengan penelitian yang pernah dilakukan Maharsari (2018) yang menyebutkan bahwa tinggi badan remaja SMP Muhammadiyah 2 Surakarta tidak berhubungan dengan asupan kalsium. Penelitian lain yang sejalan dilakukan Sari (2011) juga menyebutkan bahwa antara status gizi berdasarkan IMT/U dan TB/U dengan asupan kalsium dari makanan pada anak sekolah usia 10 - 12 tahun di SDN X, Kampung Serang, Kabupaten Bekasi tidak memiliki hubungan bermakna. Begitu juga penelitian yang pernah dilakukan Sundari (2016), hasilnya menunjukkan bahwa tidak terdapat hubungan signifikan antara asupan seng, dan zat besi dengan z-score $\mathrm{TB} / \mathrm{U}$.

Data hasil wawancara Food Recall dalam penelitian ini tidak dapat menggambarkan kebiasaan makan siswi karena makanan yang dikonsumsi selama beberapa hari tidak dapat memberikan efek pertambahan tinggi badan secara langsung. Dari data hasil food recall dapat diketahui bahwa banyak siswi yang tidak rutin makan tiga kali sehari dan konsumsi bahan makanan sumber protein, kalsium dan zink juga kurang. Sementara jajanan yang tersedia dan dikonsumsi di sekolah juga tidak banyak menyumbang asupan protein, kalsium dan zink, seperti minuman bersoda, minuman kemasan dan makanan ringan rendah kalori (chiki, kerupuk aci, dan bakso aci).

Faktor lain yang yang menyebabkan tidak ada hubungan antara asupan kalsium dan zink dengan kejadian stunting dalam penelitian ini yaitu penyakit infeksi dan faktor genetik, dimana karena keterbatasan penelitian ini, data mengenai riwayat penyakit infeksi dan genetik keturunan siswi tidak dapat digali dalam penelitian ini. Faktor asupan makanan dan penyakit infeksi merupakan faktor langsung yang mempengaruhi kejadian stunting. Faktor genetik merupakan faktor utama yang mempengaruhi tumbuh kembang individu. Proses intruksi genetik yang terkandung di dalam sel telur akan menghasilkan kualitas dan kuantitas pertumbuhan (Adriani dan Wirjatmadi, 2012). Tinggi badan orang tua merupakan salah satu faktor resiko yang berkaitan dengan kejadian stunting. Ibu yang pendek memiliki kemungkinan melahirkan bayi yang pendek pula (Julia and Amin, 2014).

Kejadian stunting berhubungan dengan berbagai macam faktor tidak langsung. Faktor sosial demografi yang meliputi pendapatan yang rendah, pendidikan orang tua yang rendah, jumlah anggota keluarga, dan faktor ekonomi dalam rumah tangga secara tidak langsung berhubungan dengan kejadian stunting(UNICEF, WHO and The World Bank, 2014). Indikator pendapatan dihubungkan dengan malnutrisi karena akan mempengaruhi pemenuhan zat gizi keluarga dan kesempatan dalam mengikuti pendidikan formal, begitu juga dengan rendahnya pendidikan serta pengetahuan gizi (Marut, 2007).

\section{KESIMPULAN}

Hasil penelitian menunjukkan bahwa tidak hubungan asupan kalsium dan zink dengan kejadian stunting pada siswi SMP Unggulan Bina Insani Surabaya. Diperlukan penelitian lain menggunakan instrument biokimia untuk penentuan status zink dan kalsium serta meneliti variabel selain asupan makanan agar dapat mengetahui penyebab kejadian stunting pada remaja khususnya remaja putri. 
Sudiarmanto dan Sumarmi, Hubungan Asupan Kalsium dan Zink...8

\section{ACKNOWLEDGMENT}

Terima kasih penulis sampaikan kepada seluruh staf dan dosen Prodi Ilmu Gizi Unair terutama kepada dosen pembimbing atas bimbingan dan pengajaran yang diberikan kepada penulis.

\section{REFERENSI}

Adriani, M. and Wirjatmadi, B. R. (2012) Peran Gizi dalam Siklus Kehidupan. Jakarta: Kencana Prenadamedia Goup.

Adriani, M. and Wirjatmadi, B. R. (2013) Pengantar Gizi Masyarakat. Jakarta: Kharisma Putra Utama.

Aguayo, V. M. and Menon, P. (2016) 'Stop stunting: Improving child feeding, women's nutrition and household sanitation in South Asia', Maternal and Child Nutrition, 12, pp. 3-11. doi: 10.1111/mcn.12283.

Almatsier, S. (2001) Prinsip Dasar ILMU GIZI. Jakarta: Gramedia Pustaka Utama. Almatsier, S. (2009) Prinsip Dasar Ilmu Gizi. Gramedia P. Jakarta.

Almatsier, S. (2010) Prinsip Dasar Ilmu Gizi. Jakarta: Gramedia Pustaka Utama.

Amelia, A. R., Syam, A. and Fatimah, S. (2013) 'Hubungan Asupan Energi Dan Zat Gizi Dengan Status Gizi Santri Putri Yayasan Pondok Pesantren Hidayatullah Makassar Sulawesi Selatan Tahun 2013', pp. 1-15.

Aridiyah, F. O., Rohmawati, N. and Ririanty, M. (2015) 'Faktor-faktor yang Mempengaruhi Kejadian Stunting pada Anak Balita di Wilayah Pedesaan dan Perkotaan (The Factors Affecting Stunting on Toddlers in Rural and Urban Areas)', e-Jurnal Pustaka Kesehatan, 3(1), pp. 163-170. doi: 10.1007/s11746-013-2339-4.

Armelia, W. (2014) 'Hubungan Tingkat Kecukupan Protein, Kalsium dan Zink dengan Pertumbuhan Linier Anak TK'.

De Assumpcão, D. et al. (2016) 'Calcium intake by adolescents: A population-based health survey', Jornal de Pediatria, pp. 251-259. doi: 10.1016/j.jped.2015.09.004.

Balitbangkes Kemenkes RI (2013) 'Riset Kesehatan Dasar (RISKESDAS) 2013', Laporan Nasional 2013, pp. 1384. doi: 1 Desember 2013.

Balitbangkes Kemenkes RI (2018) 'Riset Kesehatan Dasar 2018', Kementrian Kesehatan Republik Indonesia, pp. 1100. doi: 1 Desember 2013.

Bueno, A. L. and Czepielewski, M. A. (2008) 'The importance for growth of dietary intake of calcium and vitamin D', Jornal de Pediatria, 84(5), pp. 386-394. doi: 10.2223/JPED.1816.

Caulfield, L. E. et al. (2006) 'Stunting, wasting, and micronutrient deficiency disorders', in D, J. et al. (eds) Disease Control Priorities in Developing Countries. 2nd edn. Washington DC: Oxford University Press, pp. 551-67.

Chastity, C. N. (2017) Hubungan Asupan Protein Dengan Kejadian Stunting Pada Remaja Di Sukoharjo Jawa Tengah. UNIVERSITAS MUHAMMADIYAH SURAKARTA.

Christiany, I., Hakimi, M. and Sudargo, T. (2009) 'Status gizi, asupan zat gizi mikro (kalsium, magnesium) hubungannya dengan sindroma premenstruasi pada remaja putri SMU Sejahtera di Surabaya', Jurnal Gizi Klinik Indonesia, pp. 29-34. doi: 10.22146/IJCN.17685.

Damayanti, A. E. (2016) Hubungan Citra Tubuh, Aktivitas Fisik, dan Pengetahuan Gizi Seimbang dengan Status Gizi Remaja Putri.

Darawati, M. (2016) Ilmu Gizi: Teori \& Aplikasi. Edited by Hardinsyah and I. D. N. Supariasa. Jakarta: EGC. Fauziah, F. and Irianto, S. E. (2015) 'HUBUNGAN STATUS GIZI DENGAN ASUPAN ZINC DAN KALSIUM PADA REMAJA USIA 10-15 TAHUN DI PROVINSI NTB NTT', Nutrire Diaita, 7(1), pp. $54-63$.

Fikawati, S., Syafiq, A. and Puspasari, P. (2005) 'Faktor-faktor yang berhubungan dengan asupan kalsium pada remaja di Kota Bandung', Universa Medicina, 24(1), pp. 24-34.

Gibson, R. S. (2005) Principles of Nutritional Assessment. Oxford University Press, USA.

Gracia-Marco, L. et al. (2010) 'Bone mass and bone metabolism markers during adolescence: The HELENA study', Hormone Research in Paediatrics, 74(5), pp. 339-350. doi: 10.1159/000314965.

Isdijoso, W. (2010) National report Indonesia. Child Poverty and Disparities in Indonesia: Challenges for Inclusive Growth.

Julia, M. and Amin, N. A. (2014) 'Faktor sosiodemografi dan tinggi badan orang tua serta hubungannya dengan kejadian stunting pada balita usia 6-23 bulan', Jurnal Gizi Dan Dietetik Indonesia, 2(3), pp. 170-177.

Jumirah, M., Lubis, Z. and Aritonang, E. (2006) 'Status Gizi Dan Tingkat Kecukupan Energi Dan Protein Anak Sekolah Dasar Di Desa Namo Gajah , Kecamatan Medan Tuntungan', pp. 73-78.

Kemenkes RI (2013a) 'Angka Kecukupan Gizi yang Dianjurkan Bagi Bangsa Indonesia', Jakarta.

Kemenkes RI (2013b) Regulation on Recommended Dietary Allowance of Indonesia (Angka Kecukupan Gizi). 
9 Media Gizi Kesmas, Vol.9, No.1, Juni 2020 Halaman 1-9

Kemenkes RI (2017) Hasil Pemantauan Status Gizi (PSG) Tahun 2017. Jakarta, Direktorat Jenderal Kesehatan Masyarakat. doi: 10.3870/tzzz.2010.07.001.

L nnerdal, B. (2000) 'Dietary Factors Influencing Zinc Absorption', The Journal of Nutrition, 130(5), pp. 13781383.

Maggini, S., Wenzlaff, S. and Hornig, D. (2010) 'Essential Role of Vitamin C and Zinc in Child Immunity and Health', International Medical Research, 38(2), pp. 386-414. doi: 10.1177/147323001003800203.

Maharsari, D. R. (2018) HUBUNGAN ASUPAN KALSIUM DENGAN TINGGI BADAN. UNIVERSITAS MUHAMMADIYAH SURAKARTA.

Marut, U. D. (2007) 'Aspek Sosial Ekonomi dan Kaitannya dengan Masalah Gizi Kurang di Kabupaten Manggarai, Nusa Tenggara Timur', Jurnal Gizi dan Pangan, 2(3), pp. 36-43.

Maspaitella, M. L. and Dieny, F. F. (2012) 'Hubungan Asupan Kalsium dan Fosfor, Indeks Massa Tubuh, Persen Lemak Tubuh, Kebiasaan Olahraga, Usia Awal Menstruasi dengan Kepadatan Tulang pada Remaja Putri', Journal of Nutrition College, 1(1), pp. 229-240.

Rahmawati, R. F. (2012) 'Pengetahuan gizi, sikap, perilaku makan dan asupan kalsium pada siswi SMA', Universitas Diponegoro, pp. 1-23.

Roohani, N. et al. (2013) 'Zinc and its importance for human health: An integrative review', Journal of research in medical sciences: the official journal of Isfahan University of Medical Sciences, 18(2), p. 144. doi: 23914218.

Rosrnalina, Y. and Ernawati, F. (2010) 'Hubungan Status Zat Gizi Mikro Dengan Status Gizi Pada Anak Remaja SLTP', Penelitian Gizi dan Makanan, 33(1), pp. 14-22.

Sari, P. (2011) Status Gizi Anak Sekolah Usia 10 - 12 Tahun dan Hubungannya dengan Asupan Kalsium Di SDN X Kampung Serang, Kabupaten Bekasi Tahun 2011. Universitas Indonesia.

Soekarti, M., Soetardjo, S. and Almatsier, S. (2011) Gizi Seimbang dalam Daur Kehidupan. Jakarta: Gramedia Pustaka Utama.

Sulistianingtias Laila E (2017) 'Hubungan Antara Asupan Zink Dengan Kejadian Stunting Pada Remaja di Sukoharjo Jawa Tengah', pp. 1-10.

Sumarmi, M. S. (2016) 'Maternal Short Stature and Neonatal Stunting: an Inter-Generational Cycle', Interna, (April).

Sundari, E. (2016) 'Hubungan asupan protein, seng, zat besi, dan riwayat penyakit infeksi dengan z-score tb/u pada balita', Artikel Penelitian UNDIP, pp. 1-24.

Supariasa, I Dewa Nyoman., Bakri, Bachyar., Fajar, Ibnu., dan Ester, M. (no date) Penilaian Status Gizi. EGC. Susetyowati (2016) Ilmu Gizi: Teori \& Aplikasi. Edited by Hardinsyah and I. D. N. Supariasa. Jakarta: EGC. Trihono et al. (2015) Pendek (Stunting) di Indonesia, Masalah dan Solusi. Edited by M. Sudomo. Jakarta: Lembaga Penerbit Balitbangkes.

Trisnawati, I. (2014) 'Hubungan Asupan Fe, Zinc, Vitamin C Dan Status Gizi Dengan Kejadian Anemia Pada Remaja Putri Di SMP Negeri 4 Batang'.

UNICEF, WHO and The World Bank (2014) 'Levels and Trends in Child malnutrition', Midwifery, p. 4. doi: 10.1016/S0266-6138(96)90067-4.

Victora, C. G. et al. (2008) 'Maternal and child undernutrition: consequences for adult health and human capital', The Lancet, 371(9609), pp. 340-357. doi: 10.1016/S0140-6736(07)61692-4.

World Health Organization (2005) Nutrition in adolescence - Issues and Challenges for the Health Sector Issues in Adolescent Health and Development WHO Library Cataloguing-in-Publication Data Nutrition in adolescence: issues and challenges for the health sector: issues in adolescent he. 